\title{
Spatial and temporal genetic variation among size classes of green turtles (Chelonia mydas) provides information on oceanic dispersal and population dynamics
}

\author{
Michael P. Jensen ${ }^{1,8, *}$, Ian Bell ${ }^{2}$, Colin J. Limpus ${ }^{3}$, Mark Hamann ${ }^{4}$, Stephen Ambar ${ }^{5}$, \\ Terrence Whap ${ }^{6}$, Charles David ${ }^{7}$, Nancy N. FitzSimmons ${ }^{1,9}$ \\ ${ }^{1}$ Institute for Applied Ecology, Faculty of Applied Science, University of Canberra, Canberra, ACT 2601, Australia \\ ${ }^{2}$ Queensland Department of Environment and Heritage Protection, Townsville, Qld 4810, Australia \\ ${ }^{3}$ Threatened Species Unit, Department of Environment and Heritage Protection, PO Box 2454, Brisbane, Qld 4001, Australia \\ ${ }^{4}$ College of Marine and Environmental Sciences, James Cook University, Townsville, Qld 4811, Australia \\ ${ }^{5}$ Former Ranger, Hammond Island Community, Torres Strait, Qld 4801, Australia \\ ${ }^{6}$ Traditional Owner, Mabuiag Island, Torres Strait, Qld 4575, Australia \\ ${ }^{7}$ Traditional Owner, Iama Island, Torres Strait, Qld 4875, Australia \\ ${ }^{8}$ Present address: Marine Mammal and Turtle Division, Southwest Fisheries Science Center, National Marine Fisheries \\ Service, National Oceanic and Atmospheric Administration, 8901 La Jolla Shores Dr., La Jolla, CA 92037, USA \\ ${ }^{9}$ Present address: Australian Rivers Institute, Griffith University, Nathan, Qld 4111, Australia
}

\begin{abstract}
Migratory marine species present challenges for conservation because of complex threats within their pelagic dispersal zones, including coastal foraging areas and extensive migration pathways, or at breeding grounds. To better understand the connectivity between green turtle rookeries and foraging populations, we sequenced the mtDNA control region of 987 turtles from 6 major foraging grounds on a $\sim 2300 \mathrm{~km}$ longitudinal transect off eastern Australia, and used mixed stock analysis (MSA) to estimate their natal origins. We investigated variation in natal origins within different size classes and over spatial and temporal scales and compared this to approximately $30 \mathrm{yr}$ of mark-recapture data. For adult turtles, we found that the northern Great Barrier Reef (nGBR) genetic stock dominated in the northern feeding grounds while the southern Great Barrier Reef (sGBR) and Coral Sea stocks dominated in the south, with a changeover of dominating stock occurring between $14^{\circ}$ and $20^{\circ} \mathrm{S}$. However, at the 3 most northern feeding grounds, we found an unexpected decrease (17-30\%) in the proportion of nGBR turtles among small immature turtles relative to large immatures and adults. Four possible hypotheses were explored, with the 2 most plausible being that (1) small immature turtles from the sGBR and other rookeries first settle in nGBR feeding grounds, but later shift to other feeding grounds as they mature, or (2) a reduced hatching success for decades from the main nGBR rookery at Raine Island has resulted in reduced recruitment into the nGBR feeding ground from this stock. These results may indicate an alarming reduction in hatching success at the largest known green turtle rookery in the world.
\end{abstract}

KEY WORDS: Mixed stock analysis $\cdot$ Migration $\cdot$ Management $\cdot$ Mitochondrial DNA $\cdot$ Genetics

\section{INTRODUCTION}

Threatened migratory marine species present unique and complex challenges for conservation management. When breeding animals cross geo-political boundaries, they may move from one country that has effective legislative and regulatory conservation policies to one that does not (Miller 2000, Campbell et al. 2009). Threats faced by migratory species at feeding grounds may be quite different from those faced at 
breeding grounds, which increases the need to identify location-specific impacts. Migration distances of 100 s to 1000 s of kilometres between foraging and breeding regions may expose animals to increased mortality from a range of natural threats, including fisheries bycatch, direct harvest, interaction with shipping, entanglement and marine pollution. For marine turtles in particular, nesting beaches may be altered, or turtles and eggs harvested, or eggs destroyed by feral predators. Coastal development may result in sub-optimal nesting habitat, or a failure of hatchling recruitment to the ocean due to light pollution or habitat destruction (Lagueux et al. 2003, Leighton et al. 2011, Salmon et al. 2012). At feeding grounds, turtles may be exposed to subsistence or commercial harvest, incidental by-catch in fisheries, and to marine pollution or loss of habitat (Lutcavage et al. 1997, Limpus 2008). Additionally, climate change impacts are expected to alter habitat quality at nesting beaches and feeding grounds in various ways (Hamann et al. 2007, Hawkes et al. 2009, Poloczanska et al. 2009, Fuentes et al. 2010, 2011). Biologists and managers need to identify populations and fully understand the stock boundaries of migratory species to effectively work towards ensuring population survival.

Green turtles Chelonia mydas are the most abundant species of marine turtle in Australia (Limpus 2008), where they nest on mainland and island beaches. Two of the world's large breeding populations are found along Australia's Great Barrier Reef: the southern Great Barrier Reef (sGBR) genetic stock and the northern Great Barrier Reef (nGBR) genetic stock (see Fig. 1) (Dethmers et al. 2006, Limpus 2008). Green turtles that hatch from these regions spend several years drifting with major ocean currents (Boyle \& Limpus 2008) before recruiting into foraging areas within coastal embayments or coral reefs at a size of 40 to $50 \mathrm{~cm}$ curved carapace length (CCL) (Limpus 2008). While some marine turtles may shift feeding ground locations as they mature (Musick \& Limpus 1997, Meylan et al. 2011), green turtles from the 2 GBR populations show strong fidelity to specific feeding grounds for extended periods, possibly decades (Limpus 2008). While most turtles have high fidelity to their original choice of feeding ground, an unquantified low level of dispersal to other feeding grounds is expected, especially for mid- to large-sized turtles (Limpus 2008).

One of the world's longest running, continuously conducted marine turtle nesting and foraging studies has been undertaken along Queensland's east coast. More than 30 yr of mark-recapture data from multiple feeding grounds have provided sex and age- class-specific demographic information that demonstrate movement patterns linking nesting beaches to feeding grounds, or vice versa, for large numbers of mature females undertaking breeding migrations within the region (Limpus \& Reed 1985, Limpus et al. 1992, 1994, 2003, 2005, 2009, Limpus 1993, Read et al. 2014). To a lesser extent, adult male breeding migrations have also been documented by these mark-recapture studies (Limpus 1993, 2008, Limpus et al. 2005). However, mark-recapture studies by themselves cannot demonstrate associations of foraging immature turtles with their natal areas without decades of study. Satellite telemetry tracking can provide information on migratory paths and additional connections between breeding and foraging for (typically) small numbers of individuals (Kennett et al. 2004, Richardson et al. 2013).

The use of genetic markers can hasten and enhance our understanding of migration and stock associations beyond that gained from traditional mark-recapture techniques or satellite telemetry, by simultaneously and quantitatively exploring data from all gender and size classes. Using genetic data for mixed stock analysis (MSA), the relative proportion of genetically differentiated nesting populations represented at a given feeding ground can be estimated (Lahanas et al. 1998, Bass et al. 1998, 2006, Bass \& Witzell 2000, Luke et al. 2004, Bowen et al. 2007, Jensen et al. 2013a). Such a study is, however, dependent on prior genetic assessment of all significant breeding populations for the species in the wider region. As with comprehensive mark-recapture studies, these genetic studies provide valuable information about the geographic range of the stocks, and on the nesting populations likely to be impacted by threats at the feeding grounds. For example, the application of MSA revealed that bycatch in Peruvian fisheries impacted breeding populations of loggerhead turtles which nest on beaches in Queensland and New Caledonia, more than $12000 \mathrm{~km}$ away (Boyle et al. 2009).

By sampling different size classes of green turtles at feeding grounds it is possible to obtain answers to questions regarding how stock composition by age class is distributed across feeding grounds and to what extent stock composition changes through time. To increase our understanding of foraging green turtle population dynamics along the east coast of Australia, we undertook a detailed MSA of green turtle aggregations at 6 major foraging grounds (see Fig. 2). This was based on mitochondrial (mt)DNA data, which included re-sequencing samples taken from nesting turtles from the recognised regional 
genetic stocks (Dethmers et al. 2006) to obtain data from a longer fragment of the control region, as well as sequencing of new samples. Genetic results were compared with $30 \mathrm{yr}$ of mark-recapture data to address the following 3 questions: (1) Does our current understanding of the use of specific feeding grounds by different breeding populations, obtained by flipper tagging of adult females, match estimates derived from MSA? (2) Does the stock composition of turtles at feeding grounds vary among size classes? (3) Is there temporal variation in the stock composition of feeding populations such that values for turtles sampled in the early 1990s differ from those sampled from the late 2000s?

\section{MATERIALS AND METHODS}

\section{Study site}

We sampled green turtles at 6 major foraging grounds spread across more than $2300 \mathrm{~km}$ of the east coast of Queensland, Australia, sampling from Torres Strait in the north to Moreton Bay in the south. Approximate sample locations for rookeries included in the analyses are provided in Fig. 1 and for feeding grounds in Fig. 2. Torres Strait (TS) foraging ground (centred on $\sim 10^{\circ} 10^{\prime} \mathrm{S}, 142^{\circ} 30^{\prime} \mathrm{E}$ ) is located between the tip of the Cape York Peninsula and New Guinea and contains a cluster of islands and reefs. The Torres Strait links the Coral Sea to the Arafura Sea and is influenced by strong tidal currents (Saint-Cast \& Condie 2006). Sampling was done at several reefs around the western, central and inner islands of Torres Strait. The southern end of Torres Strait marks the northern boundary of the GBR Marine Park. Clack Reef (CR) $\left(\sim 14^{\circ} 4^{\prime} \mathrm{S}, 144^{\circ} 15^{\prime} \mathrm{E}\right)$ is located within the nGBR. Foraging turtles at Clack Reef were the subjects of a long-term mark-recapture program from 1987 to 1997 that defined population dynamics in a nGBR reef habitat (Chaloupka et al. 2004, Limpus et al. 2009). The Howicks Group (HG) $\left(\sim 14^{\circ} 30^{\prime} \mathrm{S}\right.$, $\left.144^{\circ} 58^{\prime} \mathrm{E}\right)$ consists of 16 reefs containing large sandcovered reef platforms with seagrass meadows and algal turf, with active coral growth restricted to their margins. Edgecombe Bay (EB) $\left(\sim 20^{\circ} 6^{\prime} \mathrm{S}, 148^{\circ} 18^{\prime} \mathrm{E}\right)$ is a coastal embayment located in the Central section of the GBR Marine Park. Large patches of seagrass beds are located along the fringe of the Bay before it rapidly drops off to depths of up to $6 \mathrm{~m}$. Coral reef habitat can be found in small areas along the eastern and the western sections of the Bay. Shoalwater Bay (SB) $\left(\sim 22^{\circ} 18^{\prime} \mathrm{S}, 150^{\circ} 10^{\prime} \mathrm{E}\right)$ is a large coastal embayment also located in the Central section of the GBR Marine Park and supports a regionally large green turtle foraging population. Turtles residing in the Bay have been captured repeatedly from 1986 to the present (2015) (Chaloupka et al. 2004, Limpus et al.

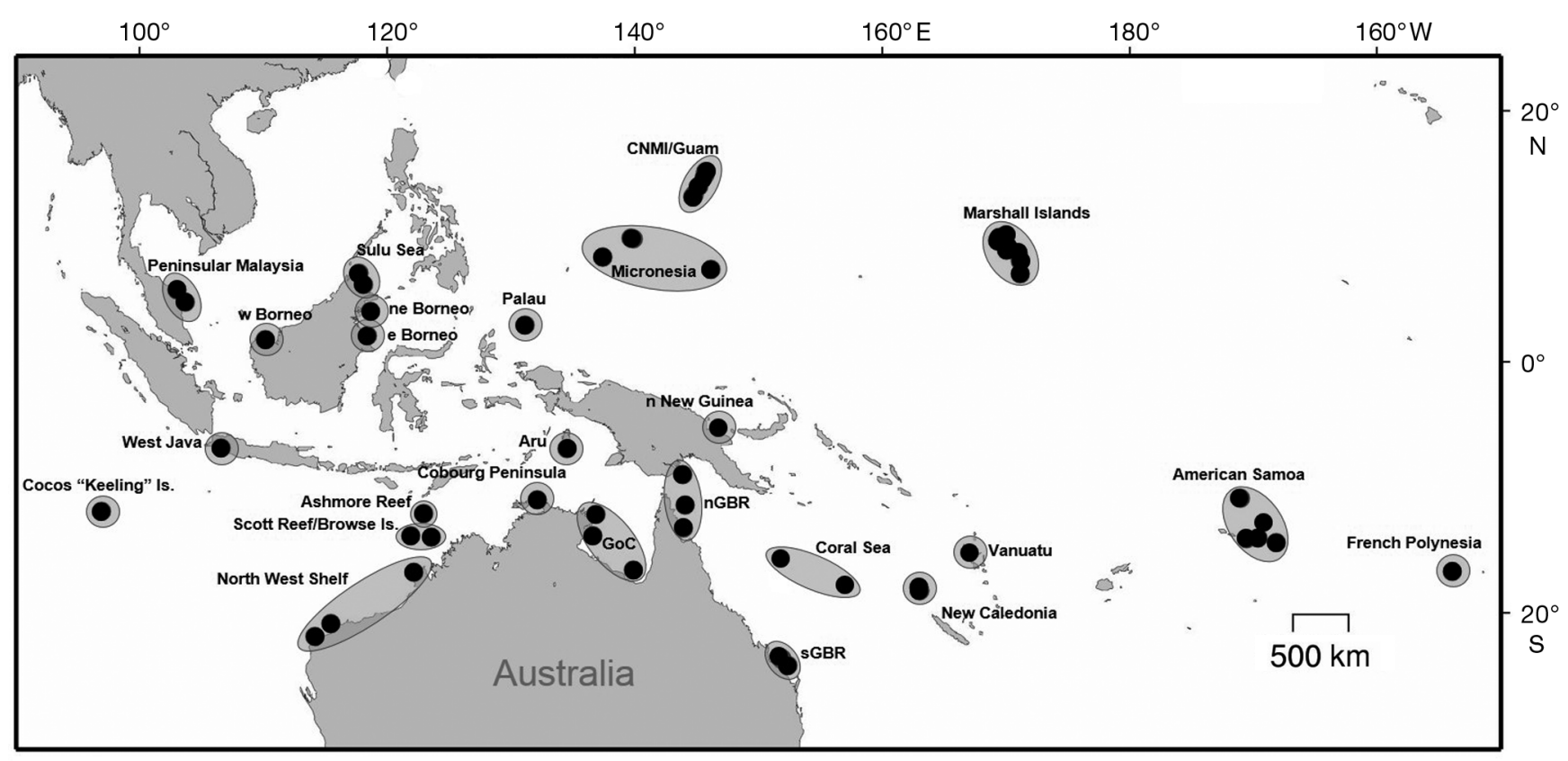

Fig. 1. Locations of 24 genetically differentiated C. mydas breeding stocks included in the MSA analysis. Black dots represent individual rookeries and shaded circles show the breeding stocks. GoC: Gulf of Carpentaria; nGBR: northern Great Barrier Reef; sGBR: southern Great Barrier Reef 


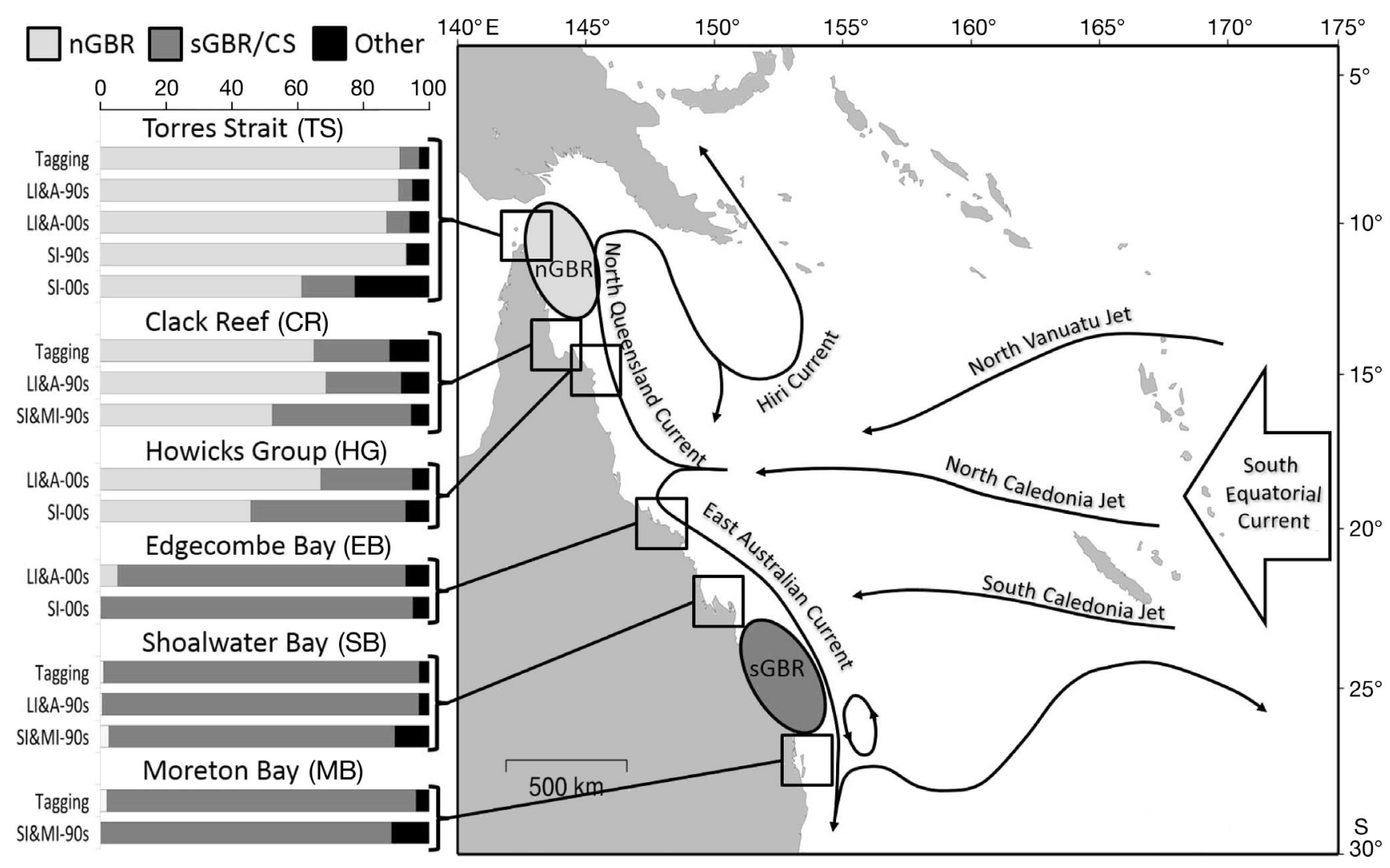

Fig. 2. Northeastern Australia and the locations of the 6 sampled feeding grounds and the mean relative contribution of northern Great Barrier Reef (nGBR), southern Great Barrier Reef and Coral Sea (sGBR/CS), and 'Other' stocks for each group sampled within the feeding grounds. Estimates are based on the mixed stock analysis using the software 'Bayes' and population size as weighted priors (Model 2). Groups are based on size categories of large immature and adult turtles (LI\&A), medium-sized immature turtles (MI) and small immature turtles (SI) and for different years of sampling (designated by the last 2 digits of the decade). Also shown are major ocean currents that are likely to affect hatchling dispersal and juvenile recruitment patterns

2005). This large embayment contains expansive intertidal seagrass beds, is fringed by mangroves and has scattered coral reef associated with rocky outcrops. Moreton Bay (MB) $\left(\sim 27^{\circ} 21^{\prime} \mathrm{S} 153^{\circ} 21^{\prime} \mathrm{E}\right)$ is a large coastal embayment offshore from the cities of Brisbane and Redland. The sampling area was contained within Moreton Bay Marine Park and represents the most southern large green turtle feeding ground in eastern Australia. Moreton Bay supports significant seagrass and mangrove areas as well as smaller areas of coral and rocky reefs. Turtles there have been the subject of ongoing long-term mark-recapture studies from 1990 to the present (2015) (Limpus et al. 1994, Chaloupka et al. 2004).

\section{Sample collection}

To establish baseline mtDNA haplotype frequencies for the nesting populations we used a total of 1715 samples from nesting females. These consisted of 714 samples from rookeries used in Dethmers et al. (2006) that were re-sequenced to obtain a longer mtDNA fragment. In addition, we increased the sample size from some rookeries and included samples from 3 new rookeries: Browse Island in Western Australia, Cocos (Keeling) Island, and Cobourg Peninsula in the Northern Territory. We also used data from the published literature for rookeries in Palau, Yap, Northern Mariana Islands, Guam, Marshall Islands, American Samoa, New Caledonia and French Polynesia (Dutton et al. 2014) as well as additional samples from New Caledonia, the Chesterfield Islands and Vanuatu (Read et al. 2015). Additional samples from 32 nesting females collected from Raine Island (nGBR) in 2008 were analysed to assess whether there was temporal variability in the genetic structure of the nGBR nesting population (Table S1 in the Supplement at www.int-res.com/articles/suppl/ m543p241_supp.xlsx).

Feeding ground samples were collected and grouped by different size classes: small immature (SI; 
35-65 cm CCL), medium-sized immature ( $\mathrm{MI} ; 66-$ $86 \mathrm{~cm} \mathrm{CCL}$ ) and large immature and adult turtles (LI\&A $;>86 \mathrm{~cm} \mathrm{CCL).} \mathrm{Contemporary} \mathrm{samples} \mathrm{were}$ collected from 2005 to 2009 and historical samples were collected in the early 1990s. This allowed for the assessment of genetic variation across size classes as well as across decades at some feeding areas. In total, the genetic sample from the 6 feeding grounds consisted of 987 individual turtles (see Table 1). All turtles were captured by rodeo-style methods (Limpus \& Reed 1985) in shallow (0.3-5 m) water, with the exception of some medium-sized immature, large immature and adult turtles from Torres Strait collected in 1990-1991. A subset of these samples ( $\mathrm{n}=$ 67 ) originated from turtles sampled while being sold at the Daru markets in Papua New Guinea, but all these turtles were harvested from within the Torres Strait (Kwan 1994). Samples were collected outside the breeding season to minimise the chance that they were non-resident turtles undertaking their breeding migration. All live turtles were flipper-tagged, curved carapace length $(\mathrm{CCL}, \pm 1 \mathrm{~mm})$ measured and a skin sample was taken from the neck and stored in a $20 \%$ DMSO solution saturated with $\mathrm{NaCl}$.

\section{Characterisation of mtDNA haplotypes}

DNA was extracted using a salting-out method (Jensen et al. 2013b) and re-suspended in a low concentration TE buffer (0.1 mM EDTA, $10 \mathrm{mM}$ Tris, $\mathrm{pH}$ 7.5). The primers LTEi9 (5'-AGC GAA TAA TCA AAA GAG AAG G-3') and H950 (5'-GTC TCG GAT TTA GGG GTT TA-3') (Abreu-Grobois et al. 2006) were used to amplify an $\sim 880 \mathrm{bp}$ fragment of the mtDNA control region. To allow comparison with known green turtle haplotypes in the published literature, sequences were truncated to $\sim 770 \mathrm{bp}$ for all genetic analyses. PCRs were performed in a $25 \mu \mathrm{l}$ volume containing $1 \times$ reaction buffer, $0.25 \mathrm{mM}$ of each deoxynucleoside triphosphate (dNTP), $10 \mu \mathrm{M}$ of each primer, $1.25 \mathrm{U}$ of Taq polymerase and $\sim 40 \mathrm{ng}$ of template DNA. The PCR protocol consisted of a 5 min denaturation step $\left(94^{\circ} \mathrm{C}\right)$ followed by 35 cycles of: $45 \mathrm{~s}$ at $94^{\circ} \mathrm{C}, 45 \mathrm{~s}$ at $52^{\circ} \mathrm{C}$, and $45 \mathrm{~s}$ at $72^{\circ} \mathrm{C}$ and a final extension step of $5 \mathrm{~min}$ at $72^{\circ} \mathrm{C}$. PCR products were purified using a PEG clean-up procedure (T. Glenn: www.mcdb.lsa.umich.edu/labs/olsen/files/PCR.pdf) and both the forward and reverse strands were sequenced by Macrogen (Macrogen Inc., Seoul, Korea). Our haplotypes were compared with known green turtle haplotypes. If similar haplotypes were not found in the initial search, a BLAST analysis was used to run a search against the Genbank database (http://blast.ncbi.nlm.nih.gov/Blast.cgi). If no similar haplotypes were identified, the sequence was identified as being unique and named accordingly. All sequences were named according to a standardized nomenclature for Indo-Pacific green turtles, using the prefix $\mathrm{CmP}$ followed by the next sequential number.

To assess the genetic diversity of each group (i.e. small immature, medium-sized immature, large immature and adult turtles within and among feeding grounds), haplotype (h) and nucleotide diversity $(\pi)$ (Nei 1987) were estimated, and an analysis of molecular variance (AMOVA) was conducted using Arlequin version 3.0 (Excoffier et al. 2005).

\section{Mixed stock analysis}

Baseline information for the mixed stock analysis (MSA) was derived from the mtDNA haplotype frequencies of 25 genetically differentiated green turtle breeding stocks across the Indo-Pacific (Fig. 1, Table S1 in the Supplement). Mixed stock analyses were conducted using a Bayesian approach to determine the origin of foraging individuals and the contribution of the different Australasian rookeries to the feeding grounds. We followed 2 commonly used approaches; the first uses the software 'Bayes' (Pella \& Masuda 2001) and estimates the proportional contributions of stocks to one feeding ground at a time. The second approach puts the analysis into a metapopulation context and can include multiple feeding grounds in one analysis, using the 'many-to-many' model (Bolker et al. 2007) in the software package R. The analyses for both methods were conducted using 2 models, one model using uniform priors (Model 1) and the other model using weighted priors (Model 2). When using uniform priors it was assumed that each rookery had the same likelihood of contributing individuals to the foraging aggregations. When using weighted priors, the contributions of different rookeries were weighted relative to the size of the rookery (mean annual number of females), under the assumption that contribution from rookeries to foraging aggregations would be proportional to rookery size.

For each analysis of MSA, 4 independent chains with different starting points were run with a burn-in of 25000 steps followed by 25000 sampling steps. The Gelman and Rubin shrink factor diagnostic was calculated to determine whether all chains had converged (shrink factor < 1.2) (Pella \& Masuda 2001). 
MSA was conducted for each group (SI, MI and LI\&A collected in early 1990s as well as SI, MI and LI\&A collected in late 2000s) within each foraging aggregation.

\section{Migration data from mark-recapture studies}

For comparison with the MSA analyses, migration data from flipper tagging was compiled from the Queensland Department of Environment and Heritage Protection's Marine Turtle Research Database for all feeding grounds. These data included tag recoveries from turtles tagged at breeding areas and recaptured at their feeding grounds or vice versa.

\section{RESULTS}

New sequence data were obtained from a $770 \mathrm{bp}$ fragment, spanning most of the mitochondrial control region, for a total of 987 foraging turtles and 826 nesting turtles. Data from an additional 889 nesting turtles from the western Pacific were available from Dutton et al. (2014) and Read et al. (2015). In total this included 107 unique haplotypes (Table S1 in the Supplement at www.int-res-com/articles/suppl/ m543p241_supp.xlsx).

\section{Identification of genetic nesting stocks}

Both the pairwise $F_{\mathrm{ST}}$ and exact tests showed significant differentiation between stocks for most comparisons, with the exception of $4 F_{\mathrm{ST}}$ tests and 2 exact tests. Non-significant results included sample locations with a small sample size $(\mathrm{n}=14-22)$ that were separated by $>1900 \mathrm{~km}$. For these reasons they were considered to be distinct breeding populations. Using longer (770 bp) sequence data added little resolution to the stock structure when compared to Dethmers et al. (2006) and identified the same management units (MU). There were 3 new rookeries included in this study; Cocos 'Keeling' Island in the Indian Ocean was identified as an independent MU, Browse Island in Western Australia grouped with the neighbouring Scott Reef MU, and Coburg Peninsula, Northern Territory, represented an independent MU. Also, recently published data from the western Pacific identified new MUs at French Polynesia, American Samoa, Marshall Islands, Northern Mariana Islands, Yap and Palau (Dutton et al. 2014); and Vanuatu, but the Chesterfield Islands grouped with the Coral Sea MU (Read et al. 2015). In total, 25 independent genetic stocks or MUs (Moritz 1994) were identified and used in further analyses.

\section{Haplotype diversity across the GBR feeding grounds}

A total of 72 haplotypes were identified across all feeding grounds. The 4 most common haplotypes were CmP47.1 (48\%), CmP44.1 (20\%), CmP80.1 (7\%) and CmP98.1 (6\%), all of which were found in high frequency within the nGBR, Coral Sea, New Caledonia and sGBR breeding stocks (Table S1 in the Supplement), which encompass the stocks breeding within the Coral Sea. Several haplotypes ( $\mathrm{n}=31$ ) were undescribed and had not been found in any rookery sampled previously (orphan haplotypes). These were found at low frequencies $(0.1-0.7 \%)$ and comprised less than $4.8 \%$ of the total sample. Within sample groups (year, size-class), these haplotypes made up $0-12 \%$ of the sample (Table S1).

A large range in genetic diversity was observed, with the lowest values found in the southern-most feeding grounds. Along the transect from Moreton Bay to Torres Strait, haplotype and nucleotide diversity was lowest in MB and SB $(\mathrm{h}=0.262-0.473$, and $\pi=0.008-0.012$ ), increased to the north and were high in $\mathrm{HG}, \mathrm{CR}$ and $\mathrm{TS}(\mathrm{h}=0.601-0.876$, and $\pi=$ 0.014-0.025) (Table 1). Additionally, the frequency of some haplotypes changed with latitude. Haplotype CmP47.1 was the most common in the southernmost feeding grounds and accounted for approximately $80 \%$ of foraging turtles at MB and SB, but decreased to account for only $12 \%$ of haplotypes at TS (Table S1). The most common haplotype, CmP44.1, increased in frequency towards the northern sites and accounted for $47 \%$ of the haplotypes in TS (Table S1).

\section{Mixed stock analysis and mark-recapture}

While the results from the many-to-many and the Bayes analyses overlapped broadly in the $95 \%$ confidence limits they did provide different results that would lead to different conclusions. Results from the many-to-many analysis indicated lower contributions from the nearest rookeries and increased contributions from more distant rookeries and those with low contributions, relative to the Bayes analysis (Table S2 in the Supplement). This same issue was reported for a study of green turtles in the Atlantic Ocean (Bolker et al. 2007). Furthermore, the estimates derived from 
Table 1. Sample size (n), number of haplotypes $(H)$, estimates $( \pm \mathrm{SD})$ of haplotype $(\mathrm{h})$ and nucleotide diversity $(\pi)$ for 6 Chelonia mydas feeding grounds along the east coast of Australia. Groups are based on size categories of large immature and adult turtles (LI\&A), medium-sized immature turtles (MI) and small immature turtles (SI) and for different years of sampling

\begin{tabular}{|lcccccc}
\hline Feeding ground & Age class & Year & $\mathrm{n}$ & $\mathrm{H}$ & $\mathrm{h}$ & $\pi$ \\
\hline Torres Strait (TS) & LI\&A & $1990-1993$ & 99 & 14 & $0.6050 \pm 0.0551$ & $0.01355 \pm 0.0069$ \\
& LI\&A & $2005-2009$ & 58 & 17 & $0.7774 \pm 0.0515$ & $0.01688 \pm 0.00855$ \\
& SI & 1992 & 16 & 4 & $0.5167 \pm 0.1324$ & $0.00888 \pm 0.00494$ \\
& SI & $2005-2009$ & 90 & 21 & $0.8762 \pm 0.0232$ & $0.0253 \pm 0.01251$ \\
Clack Reef (CR) & LI\&A & $1989-1991$ & 45 & 15 & $0.8687 \pm 0.0332$ & $0.02061 \pm 0.0104$ \\
& SI & 1991 & 22 & 7 & $0.7879 \pm 0.0557$ & $0.02147 \pm 0.01109$ \\
& MI & $1990-1991$ & 24 & 8 & $0.8225 \pm 0.0502$ & $0.02083 \pm 0.01072$ \\
Howicks Group (HG) & LI\&A & $2007-2008$ & 76 & 16 & $0.8256 \pm 0.0264$ & $0.02121 \pm 0.01059$ \\
& SI & $2007-2008$ & 85 & 18 & $0.8104 \pm 0.0346$ & $0.02336 \pm 0.0116$ \\
Edgecombe Bay (EB) & LI\&A & 2009 & 85 & 9 & $0.4807 \pm 0.0615$ & $0.01409 \pm 0.00717$ \\
Shoalwater Bay (SB) & SI & 2008 & 84 & 7 & $0.3523 \pm 0.0634$ & $0.01219 \pm 0.00626$ \\
& LI\&A & $1991-1994$ & 90 & 7 & $0.2624 \pm 0.0592$ & $0.00824 \pm 0.00437$ \\
& MI & $1989-1995$ & 44 & 11 & $0.4725 \pm 0.0935$ & $0.01155 \pm 0.00602$ \\
Moreton Bay (MB) & SI & $1989-1995$ & 44 & 6 & $0.3277 \pm 0.0889$ & $0.00965 \pm 0.0051$ \\
& MI & $1991-1994$ & 42 & 8 & $0.3844 \pm 0.0954$ & $0.00739 \pm 0.00401$ \\
& SI & $1991-1994$ & 83 & 9 & $0.3453 \pm 0.0668$ & $0.01183 \pm 0.00609$ \\
\hline
\end{tabular}

the many-to-many analysis showed differences in estimates derived from the weighted and uniform priors and were not in concordance with tag return data. For the Bayes analysis both the weighted and uniform estimates gave similar results and estimated contributions from large immature and adult turtles were almost identical to those derived from traditional tag returns (Table 2).

Given a higher concordance between the markrecapture estimates of adult turtles (Table 2) and the Bayes analyses with weighted priors (Model 2), we used the Bayes results for drawing conclusions. With the possibility that many rookeries may have contributed small numbers of turtles to the feeding areas and the uncertainty around estimating such low contributions, we grouped rookeries with $<5 \%$ estimated mean contribution into the category 'other'. Furthermore, given a high genetic similarity between the sGBR and Coral Sea MUs the MSA could not reliably distinguish between contributions from these 2 MUs. To avoid incorrect conclusions, the estimates from these 2 MUs were combined into a regional contribution from sGBR/CS and are discussed as such. Overall, the MSA suggested that the majority of foraging turtles from all 6 feeding grounds most likely originated from the nGBR, the sGBR or the Coral Sea stocks (Table 2, Fig. 2). The MSA was run for all age classes and sampling periods individually to determine whether the stock contributions differ among the evaluated groupings as presented for each feeding ground.

\section{Torres Strait}

Estimates from the Bayes Model 2 showed similar contributions from the nGBR stock of LI\&A turtles sampled in the early 1990 s $(91 \%$ nGBR, [95\%] CI = $76-99 \%$ ), and those sampled from the late 2000 s (87\% nGBR, CI $=72-99 \%$ ) (Table 2, Fig. 2). The estimates for SI turtles collected in 2005-2008 showed a lower contribution from the nGBR stock ( $61 \%$ nGBR, $\mathrm{CI}=49-75 \%$ ) in comparison to both groups of LI\&A within Torres Strait as well as SI turtles collected in 1992. Although the sample size $(n=16)$ for SI turtles collected in 1992 was small, all 16 individuals had haplotypes found in the nGBR breeding stock. To test if the difference in contribution from nGBR between SI turtles from $1992(93 \%)$ and SI turtles from 2005-2009 (61\%) was simply the effect of small sample size, we resampled $n=16$ individuals (5000 replicates) from the SI 2005-2009 haplotype distribution and recalculated the contribution from the nGBR stock for each iteration. The results from most iterations (mean $=60.18 \%$ nGBR, CI $=38.18-81.62 \%$ ) were identical to the SI 2005-2009 data, with $<0.08 \%$ of iterations resulting in a nGBR contribution $>90 \%$. This strongly suggests that the difference between SI turtles from 1992 and SI turtles from 2005-2009 was unlikely the effect of small sample size (data available upon request).

Among all TS samples there was a low contribution from the combined sGBR/CS grouping (0-7\% sGBR/CS) and from 'other' stocks $(<7 \%$ other $)$ 
Table 2. Results (mean $\% \pm 95 \%$ confidence intervals in parentheses) from the Bayesian mixed stock analysis (MSA) (Pella \& Masuda 2001) for 6 green turtle feeding grounds (FG) - TS: Torres Strait; CR: Clack Reef; HG: Howicks Group; EB: Edgecombe Bay; SB: Shoalwater Bay and MB: Moreton Bay. Each FG analysis is divided into large immature and adult turtles (LI\&A), medium-sized immature turtles (MI), and small immature turtles (SI) if sampled; year collected (year) and sample size (n). MSA was calculated using 17 regional breeding stocks as possible sources, but for simplicity only the 2 main contributors are listed-nGBR: northern Great Barrier Reef; sGBR/CS: southern Great Barrier Reef and Coral Sea combined. The combined contributions of the remaining 14 stocks are compiled into the 'Other' category. Model $1=$ uniform priors; Model $2=$ source-size weighted priors

\begin{tabular}{|c|c|c|c|c|c|c|c|c|c|}
\hline \multirow[t]{2}{*}{ FG } & \multirow[t]{2}{*}{ Stage } & \multirow[t]{2}{*}{ Year } & \multirow[t]{2}{*}{$\mathrm{n}$} & \multicolumn{2}{|c|}{$\begin{array}{c}\text { nGBR } \\
\text { Mean \% (95\% CI) }\end{array}$} & \multicolumn{2}{|c|}{$\begin{array}{c}\text { sGBR/CS } \\
\text { Mean \% (95\% CI) }\end{array}$} & \multicolumn{2}{|c|}{$\begin{array}{c}\text { Other } \\
\text { Mean \% (95\% CI) }\end{array}$} \\
\hline & & & & Model 1 & Model 2 & Model 1 & Model 2 & Model 1 & Model 2 \\
\hline TS & $\begin{array}{c}\text { A } \\
\text { LI\&A } \\
\text { LI\&A } \\
\text { SI } \\
\text { SI }\end{array}$ & $\begin{array}{c}\text { Flipper tag } \\
1990-1993 \\
2005-2009 \\
1992 \\
2005-2009\end{array}$ & $\begin{array}{c}397 \\
98 \\
58 \\
16 \\
90\end{array}$ & $\begin{array}{c}90 \\
88(76-97) \\
85(71-98) \\
89(71-99) \\
61(48-72)\end{array}$ & $\begin{array}{c}90 \\
91(76-99) \\
87(72-99) \\
93(76-100) \\
61(49-75)\end{array}$ & $\begin{array}{c}8 \\
5(0-15) \\
8(0-23) \\
1(0-5) \\
16(6-27)\end{array}$ & $\begin{array}{c}8 \\
4(0-14) \\
7(0-22) \\
0(0-3) \\
16(6-27)\end{array}$ & $\begin{array}{c}2 \\
7(2-14) \\
7(1-18) \\
10(1-29) \\
23(12-34)\end{array}$ & $\begin{array}{c}2 \\
5(1-12) \\
6(0-18) \\
7(1-24) \\
23(12-34)\end{array}$ \\
\hline CR & $\begin{array}{c}\text { A } \\
\text { LI\&A } \\
\text { SI+MI }\end{array}$ & $\begin{array}{l}\text { Flipper tag } \\
1990-1991 \\
1990-1991\end{array}$ & $\begin{array}{c}135 \\
46 \\
46\end{array}$ & $\begin{array}{c}65 \\
66(50-82) \\
50(34-68)\end{array}$ & $\begin{array}{c}65 \\
69(51-86) \\
52(35-71)\end{array}$ & $\begin{array}{c}23 \\
23(9-38) \\
41(24-59)\end{array}$ & $\begin{array}{c}23 \\
23(8-39) \\
42(23-60)\end{array}$ & $\begin{array}{c}12 \\
11(3-23) \\
9(1-21)\end{array}$ & $\begin{array}{c}12 \\
9(0-20) \\
6(0-16)\end{array}$ \\
\hline $\mathrm{HG}$ & $\begin{array}{c}\text { A } \\
\text { LI\&A } \\
\text { SI }\end{array}$ & $\begin{array}{l}\text { Flipper tag } \\
2007-2008 \\
2007-2008\end{array}$ & $\begin{array}{l}\text { na } \\
76 \\
85\end{array}$ & $\begin{array}{c}\text { na } \\
67(53-78) \\
46(34-58)\end{array}$ & $\begin{array}{c}\mathrm{n} \\
67(54-80) \\
47(35-59)\end{array}$ & $\begin{array}{c}\text { na } \\
29(16-42) \\
47(35-59)\end{array}$ & $\begin{array}{c}\mathrm{n} \\
28(15-41) \\
48(35-60)\end{array}$ & $\begin{array}{c}\text { na } \\
6(1-13) \\
7(2-14)\end{array}$ & $\begin{array}{c}\text { na } \\
5(1-12) \\
5(1-13)\end{array}$ \\
\hline EB & $\begin{array}{c}\text { A } \\
\text { LI\&A } \\
\text { SI }\end{array}$ & $\begin{array}{l}\text { Flipper tag } \\
2007-2008 \\
2007-2008\end{array}$ & $\begin{array}{l}61 \\
85 \\
84\end{array}$ & $\begin{array}{c}2 \\
5(0-12) \\
0(0-1)\end{array}$ & $\begin{array}{c}2 \\
5(0-12) \\
0(0-1)\end{array}$ & $\begin{array}{c}95 \\
87(76-95) \\
94(85-99)\end{array}$ & $\begin{array}{c}95 \\
88(77-95) \\
95(87-99)\end{array}$ & $\begin{array}{c}2 \\
9(2-20) \\
6(1-15)\end{array}$ & $\begin{array}{c}2 \\
7(1-18) \\
5(0-13)\end{array}$ \\
\hline SB & $\begin{array}{c}\text { A } \\
\text { LI\&A } \\
\text { MI } \\
\text { SI }\end{array}$ & $\begin{array}{c}\text { Flipper tag } \\
1992-1994 \\
1989-1995 \\
1989-1995\end{array}$ & $\begin{array}{c}243 \\
90 \\
44 \\
44\end{array}$ & $\begin{array}{c}1 \\
0(0-2) \\
4(0-13) \\
0(0-4 \%)\end{array}$ & $\begin{array}{c}1 \\
1(0-4) \\
4(0-14) \\
1(0-8)\end{array}$ & $\begin{array}{c}96 \\
96(89-99) \\
83(68-94) \\
88(75-97)\end{array}$ & $\begin{array}{c}96 \\
96(90-99) \\
84(69-95) \\
89(76-98)\end{array}$ & $\begin{array}{c}3 \\
4(0-11) \\
13(3-28) \\
12(3-25)\end{array}$ & $\begin{array}{c}3 \\
3(0-9) \\
12(2-26) \\
9(1-23)\end{array}$ \\
\hline $\mathrm{MB}$ & $\begin{array}{c}\text { A } \\
\text { MI } \\
\text { SI }\end{array}$ & $\begin{array}{c}\text { Flipper tag } \\
1991-1994 \\
1991-1994\end{array}$ & $\begin{array}{c}196 \\
42 \\
83\end{array}$ & $\begin{array}{c}2 \\
0(0-1) \\
0(0-1)\end{array}$ & $\begin{array}{c}2 \\
0(0-3) \\
0(0-3)\end{array}$ & $\begin{array}{c}93 \\
94(83-99) \\
85(74-93)\end{array}$ & $\begin{array}{c}93 \\
95(85-99) \\
85(74-93)\end{array}$ & $\begin{array}{c}5 \\
6(0-17) \\
15(7-26)\end{array}$ & $\begin{array}{c}5 \\
4(0-15) \\
15(7-25)\end{array}$ \\
\hline
\end{tabular}

except SI turtles sampled in 2005-2009. Estimates for that sample indicated that the combined sGBR/CS stocks contributed $16 \%(\mathrm{CI}=6-27 \%)$ and the contribution from 'other' stocks combined was $23 \%(\mathrm{CI}=$ $12-34 \%)$. Most of the 'other' contribution was estimated to have come from the Gulf of Carpentaria (GoC) $(12 \%)$ (see Table S2 in the Supplement). Mark-recapture data from 352 adult turtles resident at TS indicated a predominance $(91 \%)$ of nGBR turtles, with small $(6 \%)$ contributions from the sGBR and CS MUs, similar to the MSA results for LI\&A. A low frequency $(3 \%)$ of tag returns from 'other' stocks came from the North West Shelf, Western Australia ( $\mathrm{n}=1$ ), Piai Island, Raja Ambat, West Papua province, Indonesia $(\mathrm{n}=1)$, and Western New Caledonia $(n=2)$. However, we note that fewer turtles have been tagged outside the Great Barrier Reef region and this will bias downwards the representation of those stocks in the tag return data. Although thousands of nesting females and mating males have been flipper tagged at Bountiful Island in the south- ern Gulf of Carpentaria (GoC MU), none have been reported as captured within Torres Strait or eastern Australia.

\section{Clack Reef}

Contribution estimates from the nGBR stock at CR were also high for LI\&A (69\% nGBR, [95\%] CI = $51-86 \%)$, albeit lower than that for TS. Estimated contributions from the combined sGBR/CS $(23 \%$ sGBR/CS, CI $=8-39 \%)$ and 'other' rookeries $(9 \%$ other, $\mathrm{CI}=0-20 \%$ ) were higher than for LI\&A observed at TS. Due to the small sample size of SI (n $=22)$ and $M I(n=24)$ turtles from $C R$, these samples were combined into an estimate for small-medium immature turtles (SI+MI). Turtles from this grouping showed a lower contribution from the nGBR stock $(52 \%$ nGBR, CI $=35-70 \%)$ relative to LI\&A. Conversely, a greater contribution from the SI+MI turtles coming from sGBR/CS $(42 \%$ sGBR/CS, $\mathrm{CI}=$ 
$23-60 \%$ ) and 'other' stocks ( $6 \%$ other, $\mathrm{CI}=0-16 \%$ ) relative to aLI\&Adults from the same origins. The estimated stock contribution (65\% nGBR, $23 \%$ sGBR/CS, $12 \%$ other) derived from mark-recapture data of 42 adult females matched that from the MSA for LI\&A turtles. Tag returns from the 'other' stocks came from Papua New Guinea, New Caledonia, the Solomon Islands and the Marshall Islands.

\section{The Howicks Group}

Estimated stock contributions for the HG foraging aggregation were similar to those of CR. The estimates suggest that approximately twice as many LI\&A turtles originate from the nGBR stock in comparison to the combined sGBR/CS grouping, with a small contribution from stocks outside the GBR $(67 \%$ nGBR, [95\%] CI $=54-80 \% ; 28 \%$ sGBR/CS, CI $=$ $15-41 \%$; and $6 \%$ other, $\mathrm{CI}=1-12 \%$ ). Similar to the more northern feeding grounds, the estimated stock contribution from the nGBR among SI turtles was smaller $(47 \%, \mathrm{CI}=35-59 \%)$ than from the sGBR/CS ( $48 \%$ sGBR/CS, CI $=35-60 \%)$. Again, only small contributions from 'other' stocks $(5 \%$ other, $\mathrm{CI}=$ $1-13 \%)$ were indicated for SI turtles.

\section{Edgecombe Bay}

MSA estimates for EB indicated the main contribution shifted to the combined sGBR/CS grouping for both LI\&A (88\% sGBR/CS, [95\%] CI = 77-95\%) and SI turtles (95\% sGBR/CS, CI $=87-99 \%)$. A very low contribution from the nGBR stock was indicated for SI turtles $(0.0 \%$ nGBR, $\mathrm{CI}=0-1 \%)$ in comparison to a slightly higher estimate for LI\&A ( $5 \%$ nGBR, CI = $0-12 \%)$. A low contribution from 'other' stocks was estimated for both LI\&A ( $7 \%$ other, CI $=1-18 \%$ ) and SI turtles ( $5 \%$ other, $\mathrm{CI}=0-13 \%)$.

\section{Shoalwater Bay}

For SB, the MSA indicated that the foraging aggregation was dominated by turtles from the combined sGBR/CS grouping for LI\&A (96\% sGBR/CS, [95\%] $\mathrm{CI}=90-99 \%)$, MI (84\% sGBR/CS, CI $=69-95 \%)$ and SI turtles (89\% sGBR/CS, CI $=76-98 \%)$. Estimated contributions from the nGBR stock were small for all size classes $(<4 \%)$. Contributions from 'other' stocks were also small for LI\&A $(<3 \%$ other, $\mathrm{CI}=0-9 \%)$, but somewhat higher for MI (12\% nGBR, CI 2-26\%) and
SI turtles (9\% nGBR, CI $=1-23 \%)$. Mark-recapture data from 166 adult turtles indicated that most were from the sGBR/CS stocks (96\%), with only small contributions from the nGBR stock $(1 \%)$ and from the Coral Sea and New Caledonia (3\%). One immature turtle from the eastern Pacific green turtle MUs, which are morphologically (and genetically) distinct, has been recorded foraging on seagrass in Shoalwater Bay (Limpus et al. 2005), representing a minimal dispersal of $12900 \mathrm{~km}$ from the closest probable nesting beach in the Galapagos Islands, Ecuador.

\section{Moreton Bay}

The MB foraging aggregation was estimated to be mostly of turtles from the combined sGBR/CS grouping for MI turtles (95\% sGBR/CS, [95\%] CI = $85-99 \%)$ with very small contributions from the nGBR stock $(0 \%$ nGBR, CI $=0-3 \%)$ and 'other' stocks $(<4 \%)$. Most SI turtles originated from the sGBR/CS stock ( $85 \%$ sGBR/CS, CI $=74-93 \%$ ) with very small contributions from the nGBR stock $(0 \%$ nGBR, CI $=0-3 \%$ ). However, a larger proportion of SI turtles originated from 'other' stocks $(15 \%$ other, $\mathrm{CI}=7-25 \%$ ). Most of the turtles from the 'other' stocks were estimated to have come from New Caledonia (14\% other, CI $6-24 \%$ ) (see Table S1 in the Supplement). Mark-recapture data from 117 adult turtles resident at $\mathrm{MB}$ indicated a large contribution ( $94 \%$ ) from the sGBR/CS stocks and small contributions from the nGBR stock $(2 \%)$ and New Caledonia and Vanuatu $(4 \%$, combined). There have been recaptures in $\mathrm{MB}$ of 2 immature green turtles that were originally tagged as head-started immature turtles in French Polynesia (French Polynesia MU) and multiple captures of immature eastern Pacific green turtles (based on morphology) foraging within Moreton Bay (C.J.L. unpubl. data). Neither of these 2 genetic stocks, which breed at very great distances away, were identified within the genetic analysis of the Moreton Bay turtles.

\section{DISCUSSION}

Our extensive MSA of haplotype diversity of green turtles at feeding grounds along a $2300 \mathrm{~km}$ transect of the east Australian coast showed that 2 GBR nesting stocks were the predominant contributors and that their proportional contribution varied with latitude and among size classes. These findings have direct conservation implications. Previous mixed 
stock aMSA) estimates for marine turtle populations have resulted in large uncertainty (Bowen \& Karl 2007) which, without possibility of validation using independent information, have largely precluded detailed comparisons of stock contributions among different feeding grounds. In contrast, this study provided a unique opportunity to compare MSA and tag return data based on more than $30 \mathrm{yr}$ of marine turtle research in eastern Australia (Limpus 2008) in order to evaluate veracity in estimations. Generally, MSA results, in congruence with the mark-recapture data, support a model in which the foraging aggregations are predominantly composed of individuals from the nGBR stock and a combined grouping of the sGBR and the CS stocks. The Bayes MSA Model 2 (weighted priors) analysis suggests small (1-14\%) contributions from New Caledonia, GoC, PNG, Vanuatu, Western Australia, and Palau and the mark-recapture data specify rare contributions from Western Australia, New Caledonia, GoC, PNG, Vanuatu, the Marshal Islands, French Polynesia and eastern Pacific breeding sites. MSA depends on the relative distinctiveness of the haplotype frequencies present within the stocks and the extent to which all possible contributing stocks have been included in the analysis. In the case of the GBR stocks, large frequency differences between the nGBR and sGBR/CS stocks as well as the inclusion of samples from most of the major rookeries in the region have helped reduce the confidence intervals of results. Markrecapture studies provide evidence for direct links between individual turtles and specific nesting beaches, but rarely provide an accurate estimate of the proportion of all contributing stocks at specific feeding grounds, especially in remote regions with limited monitoring. When used together and including information spanning many decades, tagging and genetic studies in eastern Australia provide a validation for the accuracy of genetic stock assessment in foraging area studies and in our case helped select the analysis (Bayes or many-to-many) that had a greater congruence with tagging studies.

\section{Dispersal and ocean currents}

Understanding the connectivity among genetically distinct breeding stocks and various regional feeding areas, and the processes driving this is important for effective management of any threatened species. With varying anthropogenic impacts to foraging populations in different regions it is vital to estimate which stocks may be impacted and to what extent.
Affecting the distribution of turtles across feeding grounds in this study are the ocean current systems that interact with the GBR (Brinkman et al. 2002). The Southern Equatorial Current (SEC) brings water westwards across the South Pacific to the Coral Sea where it splits into 3 jets that feed into the GBR at different latitudes. The centrally located North Caledonia Jet then divides as it approaches the outer Great Barrier Reef shelf at between $14^{\circ}$ and $20^{\circ} \mathrm{S}$ latitude, (i.e. between HG and EB) and turns into the East Australian Current (EAC) running south and the North Queensland Current running north (Fig. 2).

The extent to which these major currents influence post-hatchling dispersal in eastern Australia depends on the specific rookery location, as local current patterns are dependent upon the bathymetry of nearby reef systems, winds and tides, which vary locally (Brinkman et al. 2002, Lambrechts et al. 2008, Hamann et al. 2011). Small post-hatchling green turtles emerging from rookeries in the sGBR would be carried southward with the flow of the EAC, then eastwards as the EAC turns away from the Australian coast off southeastern Australia. Eventually, posthatchlings would be carried northward into the warm water eddies within the Coral and Tasman Seas and back into the GBR via the SEC. This scenario is supported by stranding records in southern Queensland and northern New South Wales for size classes up to $10 \mathrm{~cm} \mathrm{CCL}$, that are no more than a few months old (Boyle 2006, Boyle et al. 2009). However, there is a paucity of data regarding the oceanic pelagic distribution of size ranges between 10 to $\sim 45 \mathrm{~cm}$ CCL, the size at which small immature turtles recruit back into eastern Australian coastal feeding grounds (Limpus et al. 1994, 2005) when they are expected to be 5 to $10 \mathrm{yr}$ of age (Limpus 2008). The prevalence of sGBR adult female green turtles within eastern Australian foraging areas to as far north as at least $16^{\circ} \mathrm{S}$ (Limpus et al. 2003) suggests that sGBR and Coral Sea post-hatchlings can disperse into the gyre of the North Queensland Current, perhaps when the SEC bifurcation is further north, where they establish residency at feeding grounds. Posthatchlings emerging from nGBR rookeries and any post-hatchlings carried north with the division of the SEC would be affected by water circulation within the Coral Sea Gyre and Gulf of Papua. The surface currents and eddies affecting the nGBR, Torres Strait and Gulf of Papua region are complex and vary both spatially and temporally (Andrews \& Clegg 1989, Wolanski et al. 2013). Post-hatchlings in this region may travel into the Torres Strait, remain within the gyre in the Gulf of Papua, enter the Solomon Sea, or 
be directed southwards into the EAC (Boyle 2006, Boyle et al. 2009). Such variation in current-mediated transport was observed for species of prawn, which travel from the Gulf of Papua, into the Coral Sea Gyre and then either south into the GBR, or west into Torres Strait (Dennis et al. 2001). Tag return data from nGBR nesting turtles at their feeding grounds, and MSA results indicate that the most likely routes for post-hatchlings are circulation in the Coral Sea Gyre, to enter Torres Strait and the Arafura Sea, or exiting into the Solomon Sea, or travelling south along the nGBR until they recruit back into coastal foraging areas (Limpus 2008, Limpus et al. 2009, Dethmers et al. 2010).

Haplotype distribution in the sampled green turtle feeding grounds suggests both the importance of the SEC, EAC and local wind-driven currents in distributing post-hatchling green turtles to feeding grounds along these currents, and is also consistent with the occurrence of long-distance migrations between other areas. The southern-most feeding grounds are stocked almost exclusively by turtles from the sGBR and Coral Sea MUs, which is consistent with migration pathways within the SEC and EAC. However, a small proportion of immature turtles found in GBR feeding grounds originate from New Caledonia rather than from the GBR, as is also seen in tag recoveries of adults. Additionally, numerous tag recoveries have been made of green turtles that nest in the sGBR but reside at feeding grounds in New Caledonia (Limpus 2008, Read et al. 2014) and small numbers of sGBR turtles reside in feeding grounds in Fiji $>3000 \mathrm{~km}$ distant and outside of the Coral Sea Gyre. Turtles foraging in the nGBR were more genetically diverse and had a greater number of haplotypes originating from more distant rookeries. This is corroborated by mark-recapture data from turtles that were tagged while foraging at Clack Reef, and subsequently captured at breeding sites from the Coral Sea, New Caledonia, Vanuatu, Solomon Islands and Marshall Islands; with 13 of 46 tag recoveries located 1300-3800 km from Clack Reef (Limpus 2008, Limpus et al. 2009). These various observations suggest that selection of feeding grounds for green turtles in the region is complex. As they develop, post-hatchlings are thought to drift within circulating currents while maintaining geomagnetic awareness that facilitates swimming activity to orient them within specific gyres (Lohmann et al. 2012). The extent to which selection of feeding grounds is additionally determined by individual growth rates that influence the timing of feeding ground selection, seasonal variation in current patterns, and variation in orientation behaviour remains to be understood. While most turtles at feeding grounds had haplotypes that were also identified at rookeries, the number of orphan haplotypes indicates that there are still gaps in the genetic coverage of source populations or that sample sizes from some rookeries are too small. Further sampling of green turtle breeding populations throughout the central and western Pacific is necessary to determine the origin of turtles with orphan haplotypes and to understand their migratory behaviour.

\section{Age class variation}

At the most northern feeding ground in Torres Strait, differences in haplotype profiles between recently sampled small immature (SI) turtles and all sampled large immatures and adults resulted in a major difference in the estimated stock contributions for these groups. The results suggest that over the last decade or so, fewer small immature turtles are reaching this site from the nGBR stock and higher proportions are coming from the sGBR and 'other' stocks. This trend is apparent in the 4 most northern feeding grounds, including Edgecombe Bay for which the MSA indicated a predominance of turtles from the sGBR/CS stocks. Point estimates of contributions from the nGBR stock dropped from $91 \%$ in large immatures and adults to $61 \%$ in small immature turtles in the Torres Strait, from 69 to $52 \%$ at Clack Reef, 67 to $47 \%$ in the Howicks Group and from $5 \%$ in large immatures and adults to $0 \%$ in small immature turtles in Edgecombe Bay. In most cases this was countered by increases from both the sGBR stock and from 'other' stocks, though the estimated contribution of 'other' stocks was too small to show any shifts in the Howicks Group and Edgecombe Bay samples. In contrast, the opposite result was observed at the Shoalwater Bay feeding ground, with a drop in contribution from the sGBR stock from $96 \%$ in large immatures and adults to $89 \%$ and $84 \%$ in small immature and medium-sized immature (MI) turtles, respectively, and an increase in contributions from 'other' stocks. At the most southern large feeding ground in Moreton Bay, the only comparison that could be made was between the mark-recapture data from adults and the MSA for medium-sized immature and small immature turtles. Here there was little indication of any differences between tagging data and MSA data for medium-sized immature turtles, but for small immature turtles there was a drop in contribution from the sGBR $(95 \%$ MI to $85 \%$ $\mathrm{SI}$ ) and an increase in turtles coming from New Cale- 
donia. These patterns in the stock composition of foraging turtle age classes likely resulted from several causes and 4 possible hypotheses are explored below. These are: (1) a shift in haplotype frequencies in the nGBR and sGBR/CS rookeries over time; (2) small immature turtles tend to shift feeding grounds as they mature; (3) a recent population increase in the SGBR, CS or 'other' stocks; and (4) reduced hatching success from the main nGBR rookery.

Hypothesis (1). The temporal sampling from the Torres Strait feeding ground suggests that a shift in haplotype frequencies for the nGBR rookeries could have occurred over time. Initial sampling was conducted in the early 1990s and breeding stock haplotype profiles could have changed over that time period. However, the lack of difference in haplotype frequencies of turtles nesting on Raine Island (nGBR) in 1992 and 2008 suggests temporal stability in the haplotype frequencies of the nesting population.

Hypothesis (2). Have small immature turtles shifted feeding grounds as they mature? If habitat shift during developmental migrations are a behaviour of some green turtles using the GBR, then results from the MSA of immature and adult turtles would need to be consistent with a model in which immature green turtles from several regional stocks recruit into shallow areas along the east coast of Australia. As they mature, a measurable proportion of the turtles originating from distant rookeries would shift feeding grounds and become residents at feeding grounds closer to their natal rookery. In some areas foraging habitats used by small immature turtles are geographically separated from those of adult turtles, and immature turtles may shift through a number of different feeding grounds as they mature (Lutcavage \& Musick 1985, Musick \& Limpus 1997, Pilcher 2010, Meylan et al. 2011). These shifts between foraging areas are likely driven by food abundance, food quality and/or population density (Bjorndal et al. 2000) or selective pressures to reduce the energetic costs of breeding migrations if turtles shift to areas closer to their natal region. In the Atlantic Ocean genetic data have shown that immature loggerhead turtles will recruit into benthic foraging habitats closer to their natal rookeries (Bowen et al. 2004).

However, in the Great Barrier Reef, immature and adult foraging habitats of green turtles overlap or coincide within feeding grounds and there is little evidence of developmental migrations (Limpus \& Reed 1985, Limpus et al. 1992). The mark-recapture data indicate that developmental migration of immature green turtles moving through multiple foraging areas as they mature is uncommon (Limpus \& Walter
1980, Limpus et al. 1994, 2005, Limpus \& Chaloupka 1997, Chaloupka et al. 2004). Since foraging ground tagging studies began in 1974 there have been less than 30 tag recoveries of immature green turtles making long distance changes in their foraging grounds (unpubl. data of the EHP Turtle Research data base). The potential for turtles changing feeding grounds as they mature exists but may occur at numbers too low to allow identification in mark-recapture studies, especially for turtles that shift to remote feeding grounds where there is little if any sampling effort. For example, the MSA estimates that $12 \%$ of small immature turtles sampled in the 2000s in Torres Strait originate from the Gulf of Carpentaria $(\mathrm{GoC})$, but for large immature and adult turtles the contribution from the $\mathrm{GoC}$ is close to zero.

Hypothesis (3). In support of the hypothesis that there has been a recent population increase in the sGBR, CS or 'other' stocks, long-term monitoring at Heron Island has demonstrated that the sGBR breeding population has been increasing over at least the past 4 decades (Chaloupka et al. 2008), in part due to increased hatchling production across the same period. This population was affected by an extensive commercial harvest at multiple nesting beaches for turtle soup from the later 1800s to 1950, as well as a commercial harvest from the Moreton Bay feeding ground which ceased in 1950 (Daley et al. 2008, Limpus 1980, 2008, Limpus et al. 1994). Recovery by the sGBR population was detected in the increasing size of the population foraging in coral reef habitats of the southern GBR during the 1980s and 1990s (Chaloupka \& Limpus 2001) that has continued through at least 2003 at an annual rate of $3.8 \%$ (Chaloupka et al. 2008).

If this is what is driving the observed haplotype frequency shifts between adult and immature turtles in the northern feeding grounds, then an increase in the sGBR stock contribution among immature turtles should be linked to an overall reduction in the relative frequency of all other stocks (assuming these are not increasing as well). However, there is also an increase in the proportion of immature turtles originating from rookeries outside the GBR. No monitoring data are available on the Coral Sea stock to indicate any changes in population size. Within the central-western Pacific Ocean region, there have been active community projects to reduce the take of turtles and eggs within the Regional Marine Turtle Conservation Programme of the South Pacific Regional Environmental Programme. There is a paucity of census data from the significant green turtle nesting populations from French Polynesia to New Cale- 
donia. As a consequence, an increase in the frequency of the turtles originating from rookeries outside the GBR detected in the present study cannot be linked to known increases in the nesting populations within the South Pacific island nations. Additionally, the estimated annual $3.8 \%$ increase in the sGBR population (Chaloupka et al. 2008) would not be enough to produce the observed increase in contribution from this stock in small immature turtles at the nGBR feeding grounds. This suggests that an increase in population size of the sGBR stock is not the major driver of the observed changes in haplotype frequencies.

Hypothesis (4). There have been concerns over severely reduced hatching success on Raine Island that might have been taking place over recent decades (Limpus et al. 2003, Limpus 2008). It has been speculated that changes to the beach profile resulting in inundation of nests due to a reduction in the height of sand above the water table, and in a relatively higher water table following heavy rain, in addition to higher tides and storm surges, may all contribute to this problem (Dawson \& Smithers 2010), although the specific cause has not yet been identified. Since 1996, tidal inundation and rainfall flooding over much of the nesting habitat has been a regular event at the higher tidal levels, causing a very low percentage of nests on Raine Island to produce hatchlings (Limpus et al. 2003). Given that juvenile green turtles recruit to foraging areas at around 5 to $10 \mathrm{yr}$ old, $\sim 15 \mathrm{yr}$ of low hatchling production seen at Raine Island should now be evident in juvenile cohorts. This strongly supports the patterns observed in the MSA analyses of the GBR feeding grounds and could explain much of the reduction in recruitment of nGBR small immature turtles at the nGBR feeding grounds.

\section{Conservation implications}

The Great Barrier Reef supports some of the largest nesting and foraging populations of green turtles in the world (Chaloupka et al. 2008, Limpus 2008). Managing impacts to marine turtles at foraging grounds is carried out by several state and federal agencies, community groups and inter-government co-management strategies (e.g. Grayson et al. 2010, Weiss et al. 2012). Green turtles are regarded as cultural keystone species and reductions in turtle numbers in northern Australia as a result of low hatchling production at Raine Island will impact indigenous people. In the last 10 years there has been a con- certed effort to develop indigenous community driven management in areas where there are ongoing traditional harvests. In Torres Strait, 14 community-based plans for marine turtle and dugong management are in place that function within an evolving social framework (Weiss et al. 2012). In addition, within the GBR Marine Park (GBRMP) there are currently 7 (as of October 2014) indigenous coastal communities that have developed traditional use of marine resources agreements (TUMRAs) with state and federal agencies. Collectively these agreements serve to manage resource use, including turtle management, within the GBRMP (Havemann et al. 2005).

Successful management of risks to marine turtles requires understanding the extent to which turtles from specific feeding grounds, or those exposed to specific risks, are connected to regional rookeries (Hamann et al. 2010). Importantly, anthropogenic impacts at feeding grounds can now be proportionally attributed to the relevant nesting population to help determine cumulative impacts on each stock. These data are now being incorporated into population models for use by communities and management agencies. Our study, which was conducted with the help of indigenous community groups in many of the study sites, demonstrates that using both conventional mark-recapture programs and MSA together is a useful management tool for migratory species that present challenges for managers due to spatial and temporal complexity.

The decreased proportion of nGBR individuals among the small immature turtles when compared to the large immature and adult turtle component is likely the result of multiple causes, including a reduced hatching success at the Raine Island rookery. These are complex interactions and at present there are insufficient data to rate the relative importance of these processes. If developmental migrations are occurring within the green turtle stocks that use the GBR feeding grounds, then there is a need to increase research efforts at foraging grounds throughout the region to better understand this phenomenon. If reduced hatching success at Raine Island is the main force driving the observed pattern, more research is urgently needed to quantify hatching success from the island and recruitment of juvenile turtles into the nGBR foraging areas; doing this will allow more targeted mitigation actions. In this case, importantly, the genetic data provide a 20 to $30 \mathrm{yr}$ window into the future in which the nBGR adult population may experience a severe decline. Such implied future changes in the proportions of females nesting in both the sGBR and nGBR cou- 
pled with changes to proportions of these stocks at foraging areas would influence the effect of anthropogenic mortality on regional rookeries in the near future. Reductions in the proportion of nGBR turtles at nGBR feeding grounds is concomitant with increases in the relative frequencies of sGBR and other rookeries at those feeding grounds. Without mitigation of the issues at Raine Island these trends are likely to continue. Consequently the mortality of turtles at the northern feeding grounds, such as through direct harvest, would begin to impact more on the sGBR and other stocks. As such, impacts on both nGBR and sGBR rookeries could be expected to increase during the next $20+\mathrm{yr}$. At present, the nGBR stock has signs of being in decline (Limpus et al. 2003), while the sGBR stock shows signs of increasing (Chaloupka 2002), emphasising the need for prioritised long-term stock-specific management strategies and continuation of population monitoring at both foraging and nesting sites. The combined strength of data derived from mark-recapture studies, demographic studies to determine life history parameters, genetic studies to determine stock composition and satellite telemetry to determine migratory patterns provides the needed information for making informed population assessments necessary for guiding sustainable management of marine turtles.

Acknowledgements. The Torres Strait samples were collected as part of a project funded by the Australian Government's Marine and Tropical Sciences Research Facility and the Torres Strait Regional Authority Turtle and Dugong Project. We thank the community councils of Hammond and Iama Islands, the Mabuiag Ranger group and the Kaurareg Aboriginal Council. In addition, turtle and dugong officers from several Torres Strait islands assisted in the data collection. Staff, particularly Duncan Limpus, and numerous volunteers of the DERM Queensland Turtle Conservation Project provided assistance in the capture and genetic sampling of turtles within the Great Barrier Reef Marine Park and the Moreton Bay Marine Park. We also thank Erin LaCasella and Tomoharu Eguchi for valuable comments on the manuscript. These feeding ground studies were funded in part by grants from the Australian Research Council, Great Barrier Reef Marine Park Authority and by DERM. Samples were collected under Queensland Turtle Research Project permit number G03/9866.1.

\section{LITERATURE CITED}

Abreu-Grobois FA, Horrocks JA, Formia A, Dutton P and others (2006) New mtDNA D-loop primers which work for a variety of marine turtle species may increase the resolution of mixed stock analysis. In: Frick $M$, Panagopoulou A, Reed AF, Williams K (eds) Proc 26th Annu Symp on Sea Turtle Biology, Book of Abstracts. ISTS, Crete, p 179
Andrews JC, Clegg S (1989) Coral Sea circulation and transport deduced from modal information models. Deep-Sea Res 36:957-974

Bass AL, Witzell WN (2000) Demographic composition of immature green turtles (Chelonia mydas) from the East Central Florida coast: evidence from mtDNA markers. Herpetologica 56:357-367

Bass AL, Lagueux CJ, Bowen BW (1998) Origin of green turtles, Chelonia mydas, at 'Sleeping Rocks' off the northeast coast of Nicaragua. Copeia 1998:1064-1069

Bass AL, Epperly SP, Braun-McNeill J (2006) Green turtle (Chelonia mydas) foraging and nesting aggregations in the Caribbean and Atlantic: impact of currents and behavior on dispersal. J Hered 97:346-354

> Bjorndal KA, Bolten AB, Martins HR (2000) Somatic growth model of juvenile loggerhead sea turtles Caretta caretta: duration of pelagic stage. Mar Ecol Prog Ser 202:265-272

- Bjorndal KA, Bolten AB, Chaloupka MY (2003) Survival probability estimates for immature green turtles Chelonia mydas in the Bahamas. Mar Ecol Prog Ser 252: 273-281

Bjorndal KA, Bolten AB, Troëng S (2005) Population structure and genetic diversity in green turtles nesting at Tortuguero, Costa Rica, based on mitochondrial DNA control region sequences. Mar Biol 147:1449-1457

Bolker BM, Okayama T, Bjorndal KA, Bolten AB (2007) Incorporating multiple mixed stocks in mixed stock analysis: 'many-to-many' analyses. Mol Ecol 16:685-695

Bowen BW, Karl SA (2007) Population genetics and phylogeography of sea turtles. Mol Ecol 16:4886-4907

Bowen BW, Bass AL, Soares LS, Toonen RJ (2004) Natal homing in juvenile loggerhead turtles (Caretta caretta). Mol Ecol 13:3797-3808

Bowen BW, Grant WS, Hillis-Starr ZM, Shaver DJ, Bjorndal KA, Bolten AB, Bass AL (2007) Mixed-stock analysis reveals the migrations of juvenile hawksbill turtles (Eretmochelys imbricata) in the Caribbean Sea. Mol Ecol 16:49-60

Boyle MC (2006) Post-hatchling sea turtle biology. PhD thesis, James Cook University, Townsville

Boyle MC, Limpus CJ (2008) The stomach contents of posthatchling green and loggerhead sea turtles in the southwest Pacific: an insight into habitat association. Mar Biol 155:233-241

> Boyle MC, FitzSimmons NN, Limpus CJ, Kelez S, VelezZuazo X, Waycott M (2009) Evidence for transoceanic migrations by loggerhead sea turtles in the southern Pacific Ocean. Proc R Soc B Biol Sci 276:1993-1999

Brinkman R, Wolanski E, Deleersnijder E, McAllister F, Skirving W (2002) Oceanic inflow from the Coral Sea into the Great Barrier Reef. Estuar Coast Shelf Sci 54:655-668

> Campbell LM, Silver JJ, Gray NJ, Ranger S and others (2009) Co-management of sea turtle fisheries: biogeography versus geopolitics. Mar Policy 33:137-145

> Chaloupka M (2002) Stochastic simulation modelling of southern Great Barrier Reef green turtle population dynamics. Ecol Model 148:79-109

> Chaloupka MY, Limpus CJ (2001) Trends in the abundance of sea turtles resident in southern Great Barrier Reef waters. Biol Conserv 102:235-249

> Chaloupka MY, Limpus CJ, Miller JD (2004) Green turtle somatic growth dynamics in a spatially disjunct Great Barrier Reef metapopulation. Coral Reefs 23:325-335

Chaloupka MY, Bjorndal KA, Balazs GH, Bolten AB and others (2008) Encouraging outlook for recovery of a once 
severely exploited marine megaherbivore. Glob Ecol Biogeogr 17:297-304

> Daley B, Griggs P, Marsh H (2008) Exploiting marine wildlife in Queensland: the commercial dugong and marine turtle fisheries. Aust Econ Hist Rev 48:227-265

Dawson JL, Smithers SG (2010) Shoreline and beach volume change between 1967 and 2007 at Raine Island, Great Barrier Reef, Australia. Global Planet Change 72:141-154

> Dennis DM, Pitcher CR, Skewes TD (2001) Distribution and transport pathways of Panulirus ornatus (Fabricius, 1776) and Panulirus spp. larvae in the Coral Sea, Australia. Mar Freshw Res 52:1175-1185

> Dethmers KEM, Broderick D, Moritz C, Fitzsimmons NN and others (2006) The genetic structure of Australasian green turtles (Chelonia mydas): exploring the geographical scale of genetic exchange. Mol Ecol 15:3931-3946

> Dethmers KEM, Jensen MP, FitzSimmons NN, Broderick D, Limpus CJ, Moritz C (2010) Migration of green turtles (Chelonia mydas) from Australasian feeding grounds inferred from genetic analyses. Mar Freshw Res 61: 1376-1387

> Dutton PH, Jensen MP, Frutchey K, Frey A and others (2014) Genetic stock structure of green turtle (Chelonia mydas) nesting populations across the Pacific islands. Pac Sci 68: 451-464

Excoffier L, Laval G, Schneider S (2005) Arlequin ver. 3.0: An integrated software package for population genetics data analysis. Evol Bioinform Online 1:47-50

Fuentes MMPB, Limpus CJ, Hamann M, Dawson J (2010) Potential impacts of projected sea-level rise to sea turtle rookeries. Aquat Conserv 20:132-139

Fuentes MMPB, Limpus CJ, Hamann M (2011) Vulnerability of sea turtle nesting grounds to climate change. Glob Change Biol 17:140-153

Grayson J, Hamann M, Marsh H, Ambar S (2010) Options for managing the sustainable use of green turtles: perceptions of Hammond Islanders in Torres Strait. Conserv Soc 8:73-83

Hamann M, Limpus CJ, Read MA (2007) Vulnerability of marine reptiles in the Great Barrier Reef to climate change. In: Johnson JE, Marshall PA (eds) Climate change and the Great Barrier Reef: a vulnerability assessment. Part II: Species and species groups. Great Barrier Reef Marine Park Authority and Australian Greenhouse Office, Townsville, p 466-496

> Hamann M, Godfrey MH, Seminoff JA, Arthur K and others (2010) Global research priorities for sea turtles: informing management and conservation in the 21st century. Endang Species Res 11:245-269

- Hamann M, Grech A, Wolanski E, Lambrechts J (2011) Modelling the fate of marine turtle hatchlings. Ecol Model 222:1515-1521

Havemann P, Thiriet D, Marsh H, Jones C (2005) Traditional use of marine resources agreements and dugong hunting in the Great Barrier Reef World Heritage Area. Environ Plan Law J 22:258-280

Hawkes LA, Broderick AC, Godfrey MH, Godley BJ (2009) Climate change and marine turtles. Endang Species Res $7: 137-154$

Jensen MP, FitzSimmons NN, Dutton PH (2013a) Molecular genetics of sea turtles. In: Wyneken J, Lohmann KJ, Musick JA (eds) The biology of sea turtles, Vol 3. CRC Press, Boca Raton, FL, p 135-154

> Jensen MP, Limpus CJ, Whiting SD, Guinea M and others (2013b) Defining olive ridley turtle Lepidochelys oli- vacea management units in Australia and assessing the potential impact of mortality in ghost nets. Endang Species Res 21:241-253

Kennett R, Mumungurritj N, Yunupingu D (2004) Migration patterns of marine turtles in the Gulf of Carpentaria, Northern Territory: implications for Aboriginal management. Wildl Res 31:241-248

Kwan D (1994) Fat reserves and reproduction in the green turtle, Chelonia mydas. Wildl Res 21:257-265

Lagueux CJ, Campbell CL, McCoy WA (2003) Nesting and conservation of the hawksbill turtle, Eretmochelys imbricata, in the Pearl Cays, Nicaragua. Chelonian Conserv Biol 4:588-602

Lahanas PN, Bjorndal KA, Bolten AB, Encalada SE and others (1998) Genetic composition of a green turtle (Chelonia mydas) feeding ground population: evidence for multiple origins. Mar Biol 130:345-352

Lambrechts J, Hanert E, Deleersnijder E, Bernard PE and others (2008) A multi-scale model of the hydrodynamics of the whole Great Barrier Reef. Estuar Coast Shelf Sci 79:143-151

Leighton PA, Horrocks JA, Kramer DL (2011) Predicting nest survival in sea turtles: when and where are eggs most vulnerable to predation? Anim Conserv 14:186-195

Limpus CJ (1980) The green turtle, Chelonia mydas, in eastern Australia. Res Monogr (James Cook Univ North Qld) $1: 1-22$

> Limpus CJ (1993) The green turtle, Chelonia mydas, in Queensland: breeding males in the southern Great Barrier Reef. Wildl Res 20:513-523

Limpus CJ (2008) A biological review of Australian marine turtle species. 2. Green turtle, Chelonia mydas (Linnaeus). Environmental Protection Agency, The State of Queensland, Brisbane

Limpus CJ, Chaloupka MY (1997) Nonparametric regression modelling of green sea turtle growth rates (southern Great Barrier Reef). Mar Ecol Prog Ser 149:23-34

Limpus CJ, Reed PC (1985) The green turtle, Chelonia mydas, in Queensland: A preliminary description of the population structure in a coral reef feeding ground. In: Grigg G, Shine R, Ehmann H (eds) Biology of Australasian frogs and reptiles. Surrey Beatty \& Sons, Sydney, p 47-52

Limpus CJ, Walter DG (1980) The growth of immature green turtles (Chelonia mydas) under natural conditions. Herpetologica 36:162-165

Limpus CJ, Miller JD, Parmenter CJ, Reimer D, McLachlan N, Webb R (1992) Migration of green (Chelonia mydas) and loggerhead (Caretta caretta) turtles to and from eastern Australian rookeries. Wildl Res 19:347-358

Limpus CJ, Couper PJ, Read MA (1994) The green turtle, Chelonia mydas, in Queensland: population structure in a warm temperate feeding area. Mem Queensl Mus 35: 139-154

Limpus CJ, Miller JD, Parmenter CJ, Limpus DJ (2003) The green turtle, Chelonia mydas, population of Raine Island and the Northern Great Barrier Reef: 1843-2001. Mem Queensl Mus 49:349-440

Limpus CJ, Limpus DJ, Arthur KE, Parmenter CJ (2005) Monitoring green turtle population dynamics in Shoalwater Bay, 2000-2004. GBRMPA Res Publ 83:1-51

Limpus CJ, Bell IP, Miller JD (2009) Mixed stocks of green turtles foraging on Clack Reef, northern Great Barrier Reef identified from long term tagging studies. Mar Turtle Newsl 123:3-5 
Lohmann KJ, Putman NF, Lohmann CMF (2012) The magnetic map of hatchling loggerhead sea turtles. Curr Opin Neurobiol 22:336-342

Luke KE, Horrocks JA, LeRoux RA, Dutton PH (2004) Origins of green turtle (Chelonia mydas) feeding aggregations around Barbados, West Indies. Mar Biol 144: 799-805

Lutcavage ME, Musick JA (1985) Aspects of the biology of sea turtles in Virginia. Copeia 1985:449-456

Lutcavage ME, Plotkin PT, Witherington BE, Lutz PLL (1997) Human impacts on sea turtle survival. In: Lutz PL, Musick JA (eds) The biology of sea turtles. CRC Press, Boca Raton, FL, p 107-136

Meylan PA, Meylan AB, Gray JA (2011) The ecology and migration of sea turtles 8. Tests of the developmental habitat hypothesis. Bull Am Mus Nat Hist 357:1-70

Miller K (2000) Pacific salmon fisheries: climate, information and adaptation in a conflict-ridden context. Clim Change 45:37-61

Moritz C (1994) Defining 'Evolutionarily Significant Units' for conservation. Trends Ecol Evol 9:373-375

Musick JA, Limpus CJ (1997) Habitat utilization and migration in juvenile sea turtles. In: Lutz PL, Musick JA (eds) The biology of sea turtles. CRC Press, Boca Raton, FL, p 137-163

Nei M (1987) Molecular evolutionary genetics. Columbia University Press, New York, NY

Pella J, Masuda M (2001) Bayesian methods for analysis of stock mixtures from genetic characters. Fish Bull 99: 151-167

Editorial responsibility: Per Palsbøll,

Groningen, The Netherlands
Pilcher NJ (2010) Population structure and growth of immature green turtles at Mantanani, Sabah, Malaysia. J Herpetol 44:168-171

Poloczanska ES, Limpus CJ, Hays GC (2009) Vulnerability of marine turtles to climate change. Adv Mar Biol 56: $151-211$

> Read TC, Wantiez L, Werry J, Farman R (2014) Migrations of green turtles (Chelonia mydas) between nesting and foraging grounds across the Coral Sea. PLoS ONE 9: e10083

Read TC, FitzSimmons NN, Wantiez L, Jensen MP and others (2015) Mixed stock analysis of a resident green turtle, Chelonia mydas, population in New Caledonia links rookeries in the South Pacific. Wildl Res 42:488-499

Richardson PB, Broderick AC, Coyne MS, Ekanayake L and others (2013) Satellite telemetry reveals behavioural plasticity in a green turtle population nesting in Sri Lanka. Mar Biol 160:1415-1426

Saint-Cast F, Condie S (2006) Circulation modelling in Torres Strait. Geosci Aust Rec 2006/18

Salmon M, Tolbert MG, Painter DP, Goff M, Reiners R (2012) Behavior of loggerhead sea turtles on an urban beach. II. Hatchling Orientation. Soc Study Amphib Reptiles 29: 568-576

> Weiss K, Hamann M, Kinney M, Marsh H (2012) Knowledge exchange and policy influence in a marine resource governance network. Glob Environ Change 22:178-188

Wolanski E, Lambrechts J, Thomas C, Deleersnijder E (2013) The net water circulation through Torres Strait. Cont Shelf Res 64:66-74

Submitted: June 9, 2015; Accepted: October 18, 2015

Proofs received from author(s): January 21, 2016 